\title{
Education physique et éducation du corps
}

Jean Le-Boulch

\section{(2) OpenEdition}

Journals

Édition électronique

URL : http://journals.openedition.org/trema/2452

DOI : $10.4000 /$ trema.2452

ISSN : 2107-0997

Éditeur

Faculté d'Éducation de l'université de Montpellier

Édition imprimée

Date de publication : 24 octobre 1997

Pagination : 23-31

ISSN : 1167-315X

\section{Référence électronique}

Jean Le-Boulch, «Education physique et éducation du corps », Tréma [En ligne], Hors série N¹ | 1997, mis en ligne le 03 janvier 2011, consulté le 22 avril 2019. URL : http://journals.openedition.org/ trema/2452 ; DOI : 10.4000/trema.2452

Ce document a été généré automatiquement le 22 avril 2019

Trema 


\title{
Education physique et éducation du corps
}

\author{
Jean Le-Boulch
}

\section{RÉSUMÉS}

L'auteur montre que jusqu'à la puberté, l'éducation physique ne saurait, pour de multiples raisons - et notamment parce qu'elle ne correspond pas aux besoins de l'enfant - se confondre avec l'enseignement des Activités Physiques et Sportives.

Continuing the work already published by the author, this paper shows how, up to puberty, PE cannot he confused with. the teaching of Physical and Sports Activities, and thisformany reasons, but particularly because it does not correspond to a child's needs.

INDEX

Mots-clés : apprentissage moteur, fonction, psychomotricité Keywords : hodily function, motor learning, psychomotricity

\section{AUTEUR}

\section{JEAN LE-BOULCH}

Directeur scientifique, école de psychomotricité de Florence, Italie 